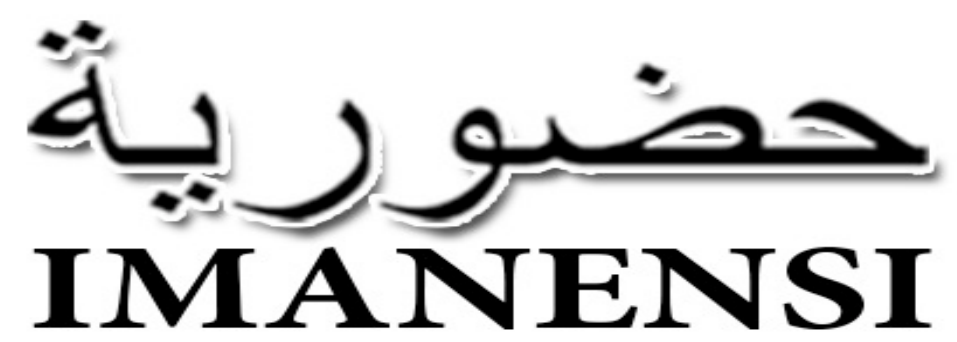

(Jurnal Ekonomi, Manajemen, dan Akuntansi Islam)

Vol 4, No 1, Maret 2019, Hlmn. 43-60

\title{
Karakteristik akuntansi dan bisnis islami: pandangan akuntan pendidik dan akuntan publik
}

Neny Jayanti, Tumirin, Umaimah

a Universitas Muhammadiyah Gresik, J1. Sumatera No.101, Gresik, Jawa Timur, Indonesia 61121

1*tumirin,ms@gmail.com

doi: 10.34202/imanensi.4.1.2019.43-60.

\begin{abstract}
Abstrak
Tujuan dari penelitian ini adalah menguji perbedaan persepsi antara akuntan pendidik dan akuntan publik akuntansi Islam. dalam penelitian ini, akuntansi Islam diukur dengan empat indikator yaitu karakteristik aktivitas bisnis Islam, akuntansi karakteristik Islam, pengguna akuntansi islam dan tujuan akuntansi Islam. penelitian ini menggunakan metode kuantitatif. kuisioner dibagikan kepada responden. jumlah responden adalah 54 akuntan pendidik dan 55 akuntan publik. hasilnya dapat disimpulkan bahwa hipotesis alternatif diterima. ada perbedaan persepsi antara akuntan pendidik dan akuntan publik akuntansi Islam
\end{abstract}

Kata Kunci: persepsi; Akuntansi Islam; akuntan pendidik; akuntan Publik.

\begin{abstract}
Aim of this research is test of difference perception betwen educator accountant and public accountant of Islamic Accounting. In this research, Islamic Accounting measured by four indicator that are business activity characteristic of Islam, characteristic accounting of Islam, Islam User accounting and gool of Islamic Accounting. This research use quantitative methods. Questionnaire distributed to responden. The number of respondens are 54 educator accountants and 55 public accountants. The result can be concluded that hypothesis of alternative is accepted. There is difference of perception between educator accountant and public accountant of Islamic Accounting

Keywords: perception; Islamic accounting; educator accountant; public accountant.
\end{abstract}

This is an open access article under the CC-BY-SA license.
(1 
Kaum Muslimin diwajibkan memilih syariah Islam dalam menjalankan bisnis atau kegiatan ekonomi. Hal tersebut seperti yang tersirat jelas dalam firman Allah SWT. Pada QS. Almaidah ayat 3 yang menjelaskan bahwa Islam adalah agama yang sempurna dan mempunyai sistem tersendiri dalam menghadapi permasalahan kehidupan, baik yang bersifat materiil maupun non materiil (Nasution, 2006; 2). Karena itu ekonomi sebagai salah satu aspek kehidupan, tentu juga sudah diatur oleh Islam. Suatu sistem yang dapat digunakan sebagai panduan bagi manusia dalam menjalankan kegiatan ekonomi. Suatu sistem yang garis besarnya sudah diatur dalam Al-Quran dan As-Sunnah. Oleh karena itu, aktivitas bisnis yang dikembangkan oleh kaum muslimin haruslah mengacu pada aturan dan hukum syariah.

Akuntansi Islami dapat dikembangkan guna memenuhi kebutuhan para pengguna muslim. Namun demikian, akuntansi Islami dikembangkan bukan hanya dengan cara "tambal sulam" terhadap akuntansi konvensional, akan tetapi merupakan pengembangan filosofi terhadap nilai-nilai Al Qur`an (Muhammad, 2002; Adnan, 2000).Di Indonesia perkembangan sistem ekonomi dan bisnis berlandaskan Islam telah menunjukkan kemajuan yang cukup menggembirakan belakangan ini. Hal tersebut dapat dilihat dari banyaknya lembaga keuangan syariah atau yang berlandaskan Islam yang muncul, menunjukkan langkah kemajuan keberadaan sistem ekonomi dan bisnis Islam di Indonesia. Lembaga-lembaga seperti itu adalah organisasi yang bercirikan "amanah" dimana didalam bisnis tersebut menerapkan Sistem Akuntansi Islami.

Mempelajari dan menerapkan Akuntansi Islami, pada hakekatnya adalah belajar dan menerapkan prinsip keseimbangan atas transaksi atau perkiraan atau rekening yang telah dicatat untuk dilaporkan kepada yang berhak mendapatkan isi laporan. Islam adalah cara hidup yang berimbang dan koheren, dirancang untuk kebahagiaan manusia dengan cara menciptakan keharmonisan antara kebutuhan moral dan material manusia dan aktualisasi sosial ekonomi, serta persaudaraan dalam masyarakat manusia.Berdasarkan alasan tersebut akuntan selaku pihak yang banyak berhubungan dengan sistem akuntansi seharusnya dapat lebih memahami karakter dan tujuan dari Akuntansi Islami, dengan lebih memahami Akuntansi Islami dapat lebih menguntungkan karena Akuntansi Islami lebih melihatkan keterbukaan dalam pembutan laporan keuangan.

Tidaklah salah jika para akuntan menerapkan dan memahami Akuntansi Islami, sebab Akuntansi Islami diperlukan dengan alasan: akuntansi konvensional tidak cukup untuk users muslim (Manajer, Pekerja/ serikat perdagangan, pemerintah, masyarakat, kreditor, penerima, zakat/ amil zakat, pelanggan/ organisasi konsumen) dan Organisasi Islam (organisasi yang dikendalikan oleh orang yang beragama Islam), Islamisasi pengetahuan, dan berdirinya Organisasi-Organisasi Islam (Hameed; 2002). Hal tersebut muncul dikarenakan: 1) Kompleksitas pengambilan keputusan saat ini tidak bisa hanya mengandalkan informasi akuntansi 2) informasi akuntansi yang selama ini dianggap sebagai dasar pengambilan keputusan ternyata banyak keputusan yang diambil dari sumber itu tidak menghasilkan output yang baik bahkan yang terjadi depresi, bangkrut, ekonomi lesu dan sebagainya 3) Unsur etika semakin longgar karena informasi akuntansi dianggap bebas nilai maka akuntansi dibawa oleh pihak yang berkepentingan sehingga bisa merugikan masyarakat. (Harahap, 2004; 3).

Mencermati berbagai hal tersebut diatas, dalam penelitian ini perlu kiranya untuk mengetahui bagaimana pemahaman akuntan dalam hal ini adalah dosen (akuntan pendidik) dan auditor (akuntan publik) mengenai karakter dan tujuan Akuntansi Islami. Dimana dosen selaku pihak yang mengajarkan dan mendidik tentang sistem akuntansi yang akan dijadikan pilihan oleh para peserta didiknya dan auditor selaku pihak yang berkecimpung langsung dalam pembuatan dan pengauditan laporan keuangan, dimana auditor merupakan pihak yang berhubungan langsung dengan perusahaan mengenai pembuatan laporan keuangan. Karena itulah penelitian ini ingin mengetahui perbedaan pandangan dan pendapat dari Akuntan pendidik dan Akuntan Publik mengenai karakter dan tujuan Akuntansi Islami yang telah berkembang di Indonesia. 


\section{METODE}

Penelitian ini menggunakan motode kuantitatif. Penelitian dilakukan pada Program Ekonomi Akuntansi pada beberapa Universitas dan Sekolah Tinggi Ekonomi yang ada di kota Gresik dan Surabaya serta lembaga Kantor Akuntan Publik yang ada di kota Surabaya. Teknik pengambilan sampel yang digunakan dalam penelitian ini secara purposive sampling yaitu suatu teknik penentuan sampel yang digunakan dengan memperhatikan ciri - ciri atau sifat yang dianggap memiliki keterkaitan dengan kriteria sampel. Purposive digunakan dalam penelitian sampel, karena responden harus mempunyai persyaratan tertentu sebagai berikut: 1) Akuntan pendidik, dengan syarat sarjana akuntansi yang bekerja sebagai staf pengajar pada perguruan tinggi. Baik sebagai staf pengajar tetap maupun staf pengajar tidak tetap pada Program Studi Akuntansi dan sarjana akuntansi tersebut harus mengajar di perguruan tinggi yang ada di kota Gresik, Surabaya dan Malang, baik yang mengajar di perguruan tinggi negeri maupun perguruan tinggi swasta; 2) Akuntan publik, sarjana Akuntansi yang bekerja sebagai auditor di Kantor Akuntan Publik (disini kami lebih memperjelas maksud dari penelitian kami, yang dapat untuk mewakili pengisian kuesioner bisa jadi dari staff dari lembaga KAP, yang sebagaimana apabila peneliti hanya meminta data dari yang memiliki lembaga KAP tersebut atau yang mempunyai gelar akuntan dimungkinkan terlambat jalannya penelitian, dikarenakan obyek yang sangat berkepentingan ini tidak berada dikantor) dan kantor para auditor harus berada di kota Surabaya.

Sumber data dalam penelitian ini berupa data primer yaitu berupa opini secara individual yang diketahui melalui hasil kuisioner yang telah disebar oleh peneliti kepada akuntan pendidik (dosen) dan akuntan publik (auditor). Metode penyebaran kuesioner dilakukan secara langsung, yaitu dengan memberikan kuesioner secara langsung kepada para akuntan pendidik dan akuntan publik. Dengan cara mendatangi perguruan tinggi dan kantor akuntan publik yang akan dijadikan sampel penelitian.

Pengukuran variabel terdiri dari: 1) Karakteristik Aktivitas Bisnis Islami. Aktivitas bisnis (ekonomi) Islami harus sesuai dengan syariah Islam dengan karakteristik adalah (adil) dan ihsan (kebaikan) (diukur melalui pertanyaan A1.1. 1, 2, 3a, 3b, 3c, 4a, 4b, 4c, 5,6); 2) Karakteristik Akuntansi Islami. Karakteristik akuntansi Islami dalam penelitian ini mengambil dua aspek karakteristik yaitu, aspek pengukuran keuangan, dan aspek disclosure dan penyajian (diukur melalui pertanyaan A1.2. 1, 2, 3, 4, 5, 6, 7, 8, 9, dan 10); 3) Pengguna Akuntansi Islami. Informasi akuntansi Islami diharapkan tidak hanya memprioritaskan investor dan kreditor, tetapi berorientasi pada stakeholder sebagai user-nya (diukur melalui pertanyaa A.2. 1, 2, 3, 4, 5, 6, 7); 4) Tujuan Akuntansi Islami, ada empat alternatif tujuan akuntansi Islami yang diusulkan, yaitu: decision usefulness, stewardship, islamic accountability, dan accountability through zakat (diukur melalui pertanyaan A.3. 1, 2, 3, 4, 5).

Berdasarkan kuesioner yang telah dibagikan responden diminta untuk memberikan jawaban tersusun dengan menggunakan skala likert dengan 5 butir jawaban. Dimana Responden diminta memilih salah satu yang mewakili pendapatnya. Skor penilaian jawaban untuk karakteristik A1.1. aktivitas bisnis Islami dan A1.2. karakteristik Akuntansi Islami (pertanyaan 1, 2, 3, 4, 5) ditentukan sebagai berikut: (1) = Sangat Tidak Setuju, (2) = Tidak Setuju, (3) = Ragu-ragu, (4) = Setuju, (5) = Sangat Setuju. Sedangkan skor untuk A1.2 karakteristik Akuntansi Islami (pertanyaan 6, 7, 8, 9, 10), A.2. para penguna Akuntansi Islami dan A.3. tujuan Akuntansi Islami adalah sebagai berikut: (1) = Tidak Penting Sama Sekali, (2) = Kurang Penting, (3) = Penting, (4) = Sangat Penting, (5) = Penting Sekali.

Penelitian ini menggunakan teknik analisis Independent-Sampel T-test. Yang digunakan untuk menguji signifikansi beda rata-rata dua kelompok dan untuk mengetahui apakah terdapat perbedaan rata-rata persepsi terhadap Akuntansi Islami dari masing-masing kelompok. Alat analisis ini digunakan karena sampel terdiri dari dua kelompok yang saling independen. 


\section{HASIL DAN PEMBAHASAN}

Akuntansi Islami. Ilmu akuntansi mengalami perkembangan dalam perjalanannya, perubahan dan perkembangan cara pandang masyarakat juga berlangsung dalam dunia ilmiah, sehingga upaya untuk mengimplementasikan Al-Qur'an dalam kehidupan sehari hari banyak diperlihatkan oleh masyarakat akhir-akhir ini. Menurut Muhammad $(2002 ; 9)$ Adapun faktor yang menyebabkan terjadinya perkembangan akuntansi hingga sekarang antara lain. Satu, adanya motivasi awal yang memaksa orang untuk mendapatkan keuntungan besar (maksimalisasi laba). Kedua, pengakuan pengusaha akan pentingnya aspek sosial yang berkaitan dengan persoalan maksimalisasi laba. Ketiga, Bisnis dilakukan dengan peranan untuk mencapai laba sebagai alat untuk mencapai tujuan bukan "akhir suatu tujuan". Dengan pernyataan lain, laba bukanlah tujuan akhir dari suatu aktivitas bisnis.

Islam melalui Al-Qur'an telah menggariskan bahwa konsep akuntansinya adalah penekanan pada pertanggung jawaban atau accountability. Hal ini dapat dilihat dalam surat Al-Baqarah ayat 282. Dalam ayat ini jelas sekali tujuan perintah ini ditekankan yaitu untuk menjaga keadilan dan kebenaran. Artinya perintah itu ditekankan pada kepentingan pertanggung jawaban agar pihak yang terlibat dalam kegiatan transaksi tidak dirugikan, tidak menimbulakan konflik, dan adil sehingga perlu para saksi. Al-Qur'an melindungi kepentingan masyarakat dengan terciptanya keadilan dan kebenaran, oleh karenanya tekanan dari akuntansi Islami adalah pertanggung jawaban bukan pengambilan keputusan (Harahap, 2004; 5). Akuntansi Islam menurut Harahap (2004: 301), bahwa Akuntansi Islam dipelajari sebagai suatu sistem akuntansi dan pada saat yang sama ditafsirkan sebagai manajemen, ekonomi, hukum, politik dan agama. Dimana keadilan agama dianggap sebagai masalah akuntansi, maka Akuntansi Islam harus dianggap sebagai salah satu turunan (perhitungan/ nisab) yaitu menganjurkan yang baik dan melarang yang jelek.

Prinsip Akuntansi Islami. Nilai yang melekat dalam Akuntansi Islami adalah nilai pertanggung jawaban, keadilan dan kebenaran. Seperti yang diuraikan dalam surat Al-Baqarah: 282. Dimana ketiga nilai tersebut sudah menjadi prinsip yang universal dalam pelaksanaan Akuntansi Islam (Muhammad, 2002:11): 1) Prinsip pertanggung jawaban. Prinsip pertanggung jawaban atau akuntabilitas (accountability) selalu berkaitan dengan konsep amanah. Persoalan amanah merupakan hasil transaksi manusia dengan sang khaliq mulai dari alam kandungan. Implikasi dalam bisnis dan akuntansi adalah bahwa individu yan terlibat dalam praktek bisnis harus selalu melakukan pertanggung jawaban apa yang telah diamanatkan dan diperbuat kepada pihak-pihak yang terikat. Dimana wujud pertanggung jawaban biasanya dalam bentuk laporan akuntansi; 2) Prinsip keadilan, Prinsip keadilan tidak saja merupakan nilai yang sangat penting dalam etika kehidupan sosial dan bisnis, tetapi juga merupakan nilai yang secara inheren melekat dalam fitrah manusia. Kata adil dalam surat Al-Baqoroh ayat: 282 secara sederhana dapat berarti bahwa setiap transaksi yang dilakukan oleh perusahaan dicatat dengan benar. Dengan demikian, kata keadilan dalam kontek aplikasi akuntansi mengandung dua pengertian yaitu: pertama, berkaitan dengan praktek moral, yaitu kejujuran yang merupakan faktor yang sangat dominan. Kedua, kata adil bersifat lebih fundamental (dan tetap berpijak pada nilai etika/syariah dan moral); 3) Prinsip kebenaran. Prinsip kebenaran ini sebenarnya tidak dapat dilepaskan dengan prinsip keadilan. Sebagai contoh misalnya, dalam akuntansi kita akan dihadapkan pada masalah pengakuan, pengukuran dan pelaporan. Aktivitas ini akan dapat dilakukan dengan baik apabila dilandaskan pada nilai kebenaran. Kebenaran ini akan dapat menciptakan keadilan dalam mengakui, mengukur, dan melaporkan transaksi-transaksi ekonomi.

Konsep Akuntansi Islami. Dalam kajian Islam, akuntansi merupakan urusan muamalah. Artinya diserahkan kapada kemampuan akal pikiran manusia untuk mengembangkannya. Dimana Al-Quran dan Sunnah hanya membekalinya dengan beberapa sistem nilai seperti landasan etika, moral, kebenaran, keadilan, kejujuran, terpercaya, bertanggung jawab dan sebagainya. Dimana instrumen tersebut sudah 
cukup sebagai landasan teoritis dari akuntnasi Islam. Sedangkan yang sifatnya teknis diserahkan sepenuhnya kepada umat manusia untuk merumuskannya sesuai kebutuhannya.

Menurut Scott (1976) dalam penyajian laporan keuangan, akuntan harus memperhatiakan semua pihak (user) dan memperlakukannya secara adil dan benar. Dan memberikan data yang akurat jangan menimbulkan salah tafsir dan jangan pula bias. Menurut Harahap $(2004 ; 151)$ struktur konsep awal Akuntansi Islami dengan model kolonial lahir dari: masyarakat Islam, ekonomi Islam, teori akuntansi Islam, praktek akuntansi Islam. Tetapi pada kenyataannya tidak ada konsep awal yang murni seratus persen sesuai dengan konsep asalnya. Yang terjadi adalah ekonomi campuran sehingga sistem ekonomi dan akuntansinya pun adalah campuran, sebagaimana dapat digambarkan sebagai berikut: masyarakat campuran, ekonomi campuran, teori akuntansi campuran, praktek akuntansi campuran.

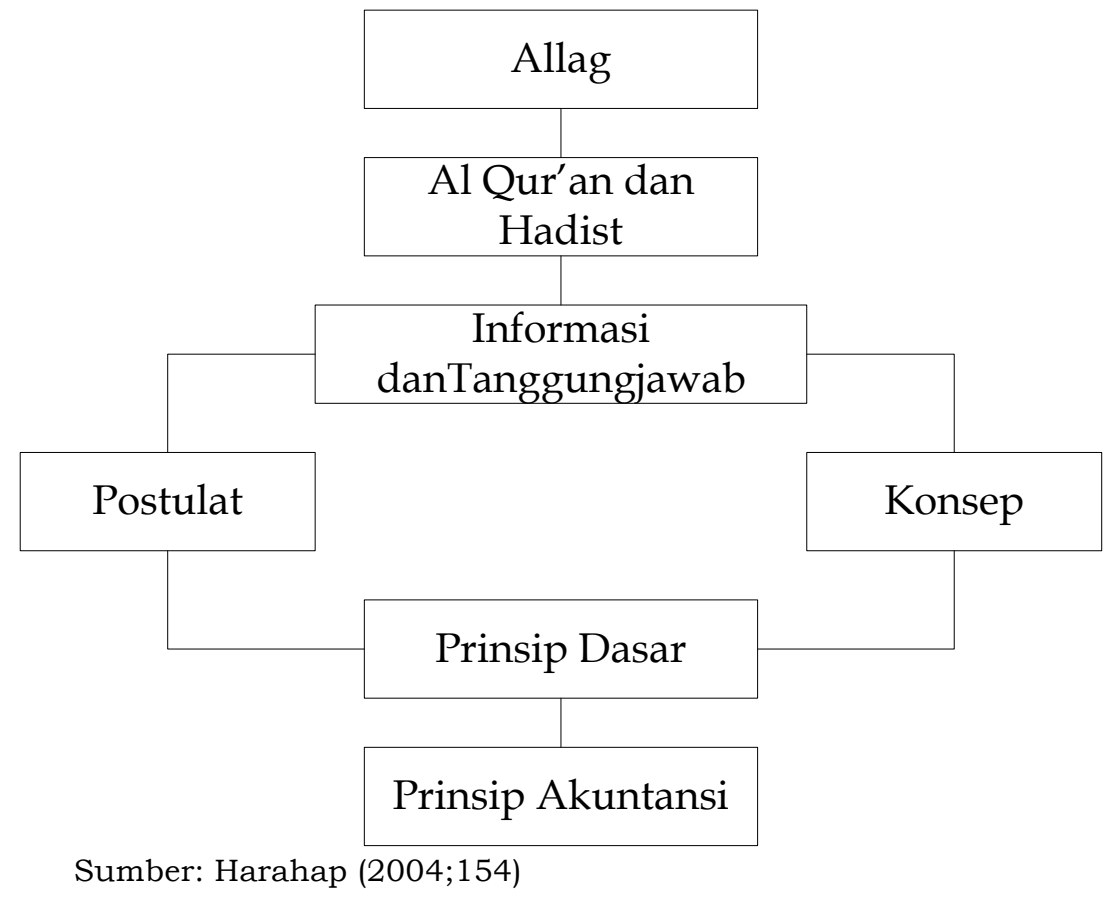

Gambar 1. Konsep dasar Akuntansi Islami

Dalam suasana seperti tersebut maka upaya yang harus dilakukan adalah bagaimana sistem campuran itu dijernihkan. Dihilangkan yang tidak sesuai dengan konsep islam dan ditambah dengan konsep yang diwajibkan Islam. Dalam konsep kapitalis banyak yang dapat dipakai dalam konsep Islam dan ada yang memang tidak sesuai dengan syariat Islam. Berdasarkan dua konsep gambar 1 maka konsep dasar Akuntansi Syariah adalah: 1) sumber hukum dari akuntansi adalah Allah melalui instrumen Al-Qur'an dan Sunnah; 2) Sumber hukum ini harus menjadi pagar pengaman dari setiap postulat, konsep, prinsip dan teknik akutansi; 3) Penekanan pada accountability, kejujuran, kebenaran dan keadilan; 4) Permasalahan diluar diserahkan sepenuhnya kepada akal pikiran manusia termasuk untuk kepentingan decision usefulness

Paradigma Akuntansi Islami. Paradigma Akuntansi Islami dikembangkan menurut masyarakat muslim dimana pengembamgan tersebut dilakukan berdasarkan interprestasi pemikiran masyarakat muslim dalam memahami akuntansi. Secara nyata paradima akuntansi Islam dapat divisualisasikan pada gambar 2 . 


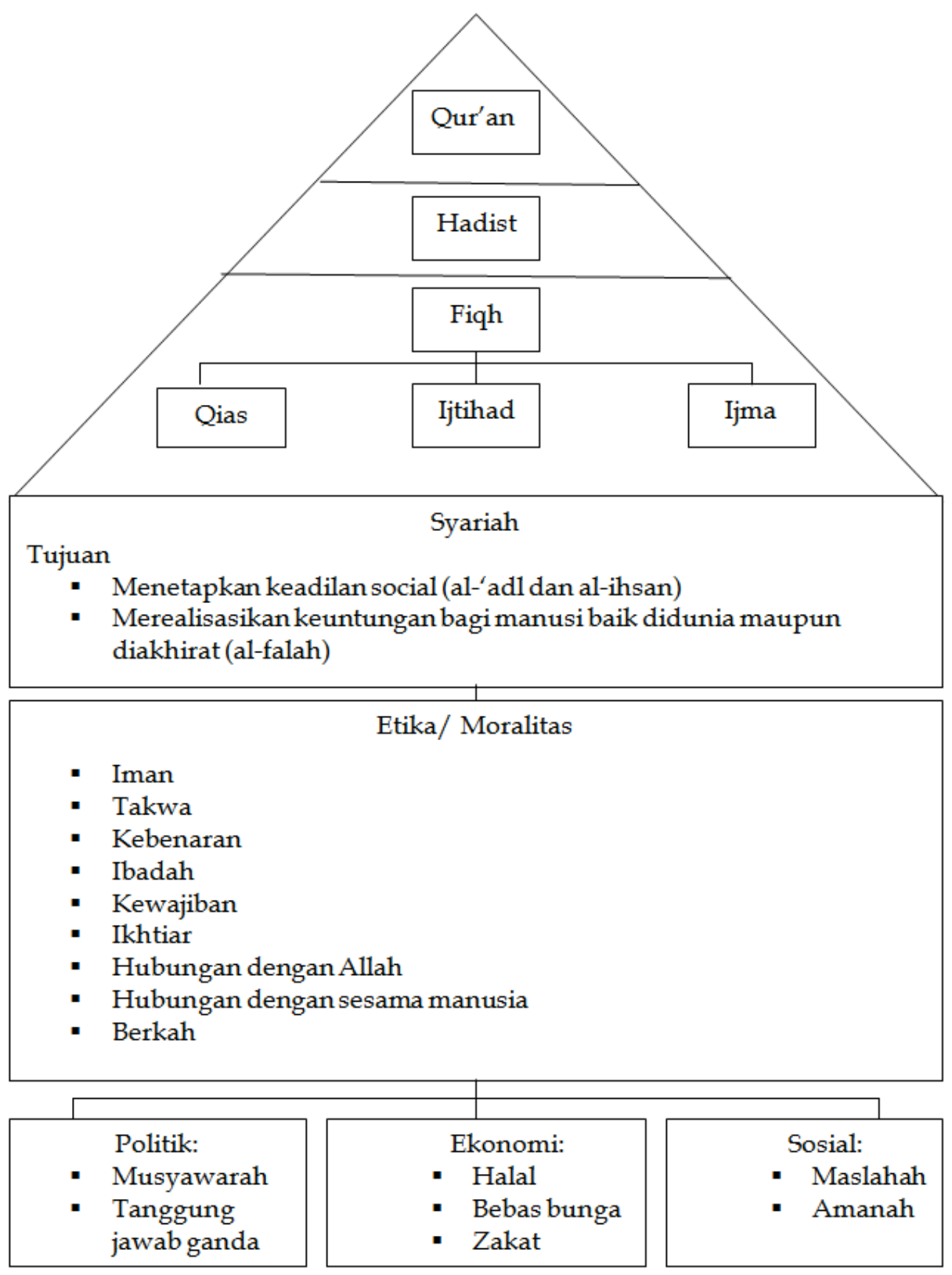

Sumber: Muhammad (2002;110)

Gambar 2. Paradigma Akuntansi Islami

Paradigma akuntansi Islami diturunkan dari tiga sumber yaitu: Al-Qur'an, Hadist dan Fiqh. Dimana susunan urutan dari ketiga sumber tersebut tidak dapat diubah ubah posisinya. Sumber yang pertama selalu Al-Qur'an, kemudian Hadist, lalu diikuti oleh Fiqh. Syariah mengatur segala aspek kehidupan manusia, baik yang mengikuti politik, ekonomi, dan sosial dengan menjaga keyakinan, kehidupan, akal dan kekayaan para umat manusia. Tujuan utama dari syariah adalah mendidik setiap uamat manusia, memantapkan keadilan dan mewujudkan keuntungan bagi umat manusia baik didunia maupun diakhirat. Dengan kata lain syariah berkaitan dengan peningkatan keadilan dan kesejahteraan masyarakat dengan meletakkan fondasi dasar bagi moral, sosial, politik dan filsafat ekonomi masrakat muslim.

Paradigma akuntansi Islami yang selanjutnya adalah berhubungan dengan aspek moral atau etika dimana aspek tersebut ditopang dengan konsep tauhid, iman dan konsep-konsep lain seperti: kebenaran, ketaqwaan, ibadah, kewajiban, dan ikhtiar. Akan tetapi tanpa kepercayaan atau iman sulit untuk mencapai aspek yang 
lainnya. Tauhid adalah, kepercayaan manusia untuk selalu bergantung kepada Allah, sebab adanya keterbatasan dari manusia. Oleh karena itu manusia perlu melakukan ibadah kepada Tuhannya.

Taqwa adalah aktivitas manusia dengan menjalan perintanya dan menjauhi laranganNya. Al-Qur'an mengatakan, jika seseorang memiliki rasa taqwa yang tinggi maka dalam hidupnya akan memiliki rasa kasih sayang dari Allah (Qs.At-Talaq: 4; A1Lail: 5-7), Orang-orang yang Taqwa akan terlindung dari api neraka (Al-Aarf: 201), Orang yang Taqwa akan mendapat perlindungan dari Allah (Qs.Al-Anfal: 34; AlJathiya: 19), Orang yang Taqwa dapat membedakan mana yang baik dan mana yang buruk (Qs.Al-Anfal: 34; Al-Hadid: 28), orang yang Taqwa mencegah ketidak adilan dalam hal aharta atau kekayaan (Qs.Al-Baqoroh: 180).

Kebenaran terdiri atas semua jenis kebaikkan dan kesempurnaan yang diharapkan manusia dalam hidupnya. Disamping mempercayai kebenaran adanya Allah dan kehidupan, manusia juga menggunakan kekayaan secara baik, membelanjakan kejalan-jaln yang dibenarkan syariah. Jika kebenaran tersebut dijalankan dan ditegakkan secara berkelanjutan, maka individu dan masyarakat akan memperoleh kedamaian dan keamanan pada setiap lapisan masyarakat. Ikhtiar adalah, menunjukkan bahwa manusia dilahirkan bebas berbuat, manusia memuliki kemampuan untuk memilih dalam situasi yang bertentangan (Qs.Al-Hasr:7). Kewajiban atau tanggung jawab dalam Islam adalah, menunjukkan pada dua konsep penting yaitu: pertama, berhubungan dengan peran manusia sebagai khalifah dibumi, kedua, usaha manusia untuk memakmurkan bumi (Qs. Al-Ra'd: 11).

Paradigma yang terakhir berhubungan dengan konsep sosial, ekonomi dan politik. Aspek sosial dalam Islam adalah didasarkan pada konsep tauhid dan al-falah maslahah dan ummah. Berdasarkan konsep persamaan ini setiap manusia mendapatkan kesempatan yang sama untuk berbuat kebenaran dalam amsyarakat. Yang dimaksu dengan Al-falah adalah, peningkatan persamaan dan kebajikan dalam masyrakat akan menjamin tercapainya keadilan. Sedangkan yang disebut dengan maslahah adalah, dengan menggunakan prinsip syariah manusia dapat menciptakan atau memberikan manfaat pada orang lain.

Aspek politik dalam Islam didasarkan pada konsep tauhid, Musyawara (syura), adil, bay'a, dan kilafah. Aspek ekonomi Islam didasarkan pada konsep tauhid, al'adl wal ihsan, ikhtiar dan kewajiban sebagaimana yang ditegaskan dalam Al-Qur'an dan Hadist. Berdasarkan pada konsep Tauhid, hak milik sepenuhnya atas segala harta kekayaan ada pada Allah dan manusia hanya diberikan amanah untuk menggunakannya sesuai dengan yang digariskan oleh syariah. Keseimbangan (al'adl wal ihsan) dalam Islam didasarkan pada konsep normatif keadilan dalam arti sempit.

Dengan demikian, aktivitas ekonomi ataupun bisnis dalam Islam merupakan bentuk ibadah. Oleh karena itu penggunaan dalam Islam harus halal menurut hukum Islam. Selanjutnya dalam melakukan aktivitas ekonomi dan bisnis harus diawali dengan akad yang jelas, dilakukan pencatatan, tidak berlebihan, moderat dalam melakukan konsumsi untuk mengurangi timbulnya kelangkaan, dan memenuhi kewajiban kepada masyarakat dengan membayar zakat. Setiap orang harus menghindari dari perbuatan memakan riba, aktivitas ekonomi dan bisnis yang menggandung unsur khiyana, tanajush, gharar dan senua bentuk spekulatif dalam transaksi bisnis, ini semua diinginkan agar keadaan ekonomi yang berkeadilan dengan berdasarkan pada kesamaan dan transparansi.

Karakteristik Akuntansi Islami. Karakteristik dalam akuntansi Islami difokuskan pada dua aspek yang penting yaitu meliputi 1) Pengukuran keuangan, 2) pengungkapan (Yaya, 2004). Menurut Zaid (1997) Sebagian besar literatur Akuntansi Islami mengambil Zakat sebagai dasar penentuan alat pengukuran. Terdapat, paling tidak, tiga alasan untuk mengambil Zakat sebagai fokus utama dari masalah pengukuran. Pertama, Zakat adalah konsep dalam Islam yang secara khusus berkaitan dengan pengukuran aset. Kedua, Zakat telah diputuskan dalam banyak ayat-ayat langsung setelah ordonansi doa dan dianggap sebagai salah satu dari lima pilar Islam. Hal ini menunjukkan bahwa umat Islam didorong untuk membangun 
instrumen (termasuk instrumen akuntansi) untuk memastikan kewajiban ini dapat dipenuhi sesuai dengan Shariah Islam. Ketiga, pengembangan akuntansi pada awal pemerintahan muslim yang erat kaitannya dengan praktek Zakat.

Yaya dan Hameed (2004) memandang bahwa zakat sebagai bagian penting dalam penentuan alat pengukuran karena zakat behubungan dengan pengukuran aset yang mengatur nisab dan haul. Standar akuntansi zakat menggunakan penilaian current exchange value (nilai tukar sekarang) atau harga pasar. Haniffa dan Hudaib (2001) mengemukakan bahwa pentingnya pengungkapan dan presentasi adalah untuk memenuhi tugas dan kewajiban sesuai dengan Syariah Islam. Untuk mencapai tujuan tersebut, maka perusahaan diharapkan mengungkapkan: 1) transaksi terlarang (haram) yang dilakukan, 2) kewajiban zakat yang seharusnya dibayarkan, dan 3) tanggung jawab sosial. Ini berarti laporan keuangan dalam masyarakat Islam lebih detail dibanding masyarakat barat.

Menurut Prayudi (2007) karakteristik perbedaan antara prinsip Akuntansi Islami dengan akuntansi konvensional adalah akuntansi syariah tidak mengenal riba dalam prakteknya, tidak mengenal konsep time-value of money, uang sebagai alat tukar bukan sebagai komoditi yang diperdagangkan serta menggunakan konsep bagi hasil. Hal ini sejalan dengan konsep Islam seperti yang tercantum dalam Al-Quran.

Tujuan Akuntansi Islami. Adapun tujuan yang ingin dicapai dalam Akuntansi Islami adalah dalam rangka menyajikan laporan keuangan secara benar sehingga diperoleh informasi yang akurat sebagai dasar perhitungan zakat (Prayudi, 2007). Yaya dan Hameed (2004) dalam penelitiannya mengusulkan sejumlah tujuan akuntansi Islami, yaitu: 1) decision usefulness, 2) stewardship, 3) Islamic accountability, dan 4) Accountability through zakat. Keputusan kegunaan dapat diartikan sebagai kebutuhan mencari pihak-pihak yang melakukan pemantauan atau ikhtisar atas peran sosial kinerja korporasi. Namun, sebagian besar literatur tentang keputusan kegunaan hanya berkaitan dengan kebutuhan pemegang saham dan kreditor. Oleh karena itu, informasi yang berguna terutama yang berhubungan dengan, (1) kemampuan untuk memprediksi apabila investor akan menerima dividen dan jumlah yang terlibat (atau berapa banyak mereka akan menerima jika mereka menjual saham) dan (2) kemampuan untuk mengetahui apakah perusahaan tersebut mampu membayar pinjaman dari kreditor (atau berapa banyak mereka akan menerima jika mereka menjual atau menebus mereka obligasi).

Akuntansi Islami berdasarkan pandangan Hameed (2002) sebagai dua pertanggungjawaban. Akuntabilitas pertama muncul dari konsep khalifah yang menganggap manusia sebagai wakil Allah swt. di muka bumi dengan selalu menggunakan pedoman Al Qur'an dan Al Hadits sebagai sumber hukum utama dalam Islam. Akuntabilitas kedua terjadi karena suatu perjanjian antara pemilik atau investor dengan manajer. Untuk melaksanakan kedua akuntabilitas tersebut, perusahaan haruslah mengidentifikasi, mengukur, dan melaporkan aktivitas sosiolekonomi yang berhubungan dengan Islam, sosial, ekonomi, dan lingkungan.

Adnan dan Gaffikin (1997) dalam Yaya dan Hameed (2004) menegaskan bahwa tujuan utama informasi Akuntansi Islami adalah penyediaan informasi untuk memenuhi suatu kewajiban akuntabilitas kepada pemilik sebenarnya (Allah). Dengan demikian, secara keseluruhan akan lebih baik pertanggung jawaban operasional, jika diarahkan kepada pemenuhan dari Zakat, dengan menjadikan Zakat tujuan utama, kita cenderung untuk menghindari praktik kecurangan yang tidak diinginkan dalam bentuk apapun, karena percaya bahwa Allah mengawasi kita. Dengan demikian informasi akuntansi akan langsung pada para penggunanya memenuhi kebutuhan juga sebagai tanggung jawab sosial.

Triyuwono (2000:6) mendukung bahwa organisasi muslim seharusnya zakat oriented selain profit oriented. Hal ini berarti bahwa net profit tidak digunakan sebagai dasar pengukur kinerja, tetapi sebaliknya, zakat menjadi ukuran kinerja perusahaan. Dengan orientasi zakat, perusahaan berusaha untuk mencapai "angka" pembayaran zakat yang tinggi. Susanto (2002) menyebutkan bahwa zakat sebagai aktivitas ekonomis-religius mengandung lima unsur penting: (1) kepercayaan keagamaan, (2) 
pemerataan dan keadilan, (3) kematangan dan produktif, (4) kebebasan dan nalar, (5) etik dan kewajaran.

Deskripsi Hasil Penelitian. Dalam penelitian ini telah disebarkan sebanyak 109 kuisioner kepada akuntan pendidik dan akuntan publik. Dengan rincian akuntan pendidik sebanyak 54 kuisioner, yang disebar pada 7 universitas yang tersebar diwilayah Gresik, Surabaya dan Malang. Sedangkan untuk akuntan publik kuisioner yang tersebar sebanyak 55 kuisioner yang tersebar pada 11 Kantor Akuntan Publik di wilayah Surabaya.

Tabel 1. Prosentase Kuesioner Untuk Akuntan Pendidik

\begin{tabular}{ccccc}
\hline & \multicolumn{4}{c}{ Kuesioner } \\
\cline { 2 - 5 } Perguruan Tinggi & Tersebar & Kembali & $\begin{array}{c}\text { Tidak } \\
\text { Kembali }\end{array}$ & $\begin{array}{c}\text { Tidak } \\
\text { Memenuhi } \\
\text { Kriteria }\end{array}$ \\
\hline UMG & 9 & 9 & 0 & 0 \\
\hline STIENU & 5 & 5 & 0 & 0 \\
\hline PERBANAS & 10 & 10 & 0 & 0 \\
\hline STIESIA & 10 & 10 & 0 & 0 \\
\hline UNTAG & 10 & 7 & 3 & 0 \\
\hline WEARNES & 5 & 4 & 1 & 0 \\
\hline UNAIR & 5 & 0 & 5 & 0 \\
\hline Total & 54 & 45 & 9 & 0
\end{tabular}

Sumber: Dokumen peneliti

Tabel 2. Prosentase Kuesioner Untuk Akuntan Publik

\begin{tabular}{lcccc}
\hline & \multicolumn{3}{c}{ Kuesioner } & \\
\cline { 2 - 5 } Perguruan Tinggi & Tersebar & Kembali & $\begin{array}{c}\text { Tidak } \\
\text { Kembali }\end{array}$ & $\begin{array}{c}\text { Tidak } \\
\text { Memenuhi } \\
\text { Kriteria }\end{array}$ \\
\hline Bambang Siswanto & 3 & 3 & 0 & 0 \\
\hline Hadori & 3 & 3 & 0 & 0 \\
\hline Basri HarjoSumarto & 5 & 5 & 0 & 0 \\
\hline J Tanzil & 15 & 15 & 0 & 0 \\
\hline Made, Thomas, Dewi & 5 & 5 & 0 & 0 \\
\hline Agus Iwan Sutanto & 3 & 3 & 5 & 0 \\
\hline Haryono, Adi dan Agus & 10 & 5 & 0 & 0 \\
\hline Sasongko dan Sidharta & 3 & 3 & 0 & 0 \\
\hline Ernest And Young & 3 & 3 & 3 & 0 \\
\hline Mudjianto & 3 & 0 & 2 & 0 \\
\hline Didy tjiptohadi \& rekan & 2 & 0 & 10 & 0 \\
\hline \multicolumn{1}{c}{ Total } & 55 & 45 & 18 & 0 \\
\hline \multicolumn{1}{c}{ Prosentase } & 100 & 82 & 0 & 0 \\
\hline
\end{tabular}

Sumber: Dokumen peneliti

Berdasarkan tabel 3 dapat disimpulkan bahwa KABI (karakteristik aktivitas bisnis islami) memiliki rata-rata 4,0256 dengan std Deviation 0,45581 yang berarti bahwa responden akuntan pendidik dan akuntan publik setuju terhadap karakteristik aktivitas bisnis Islami, hal tersebut ditunjukkan dalam menjawab kuesioner rata-rata menjawab angka 4 yang berarti setuju. KAI (Karakteristik 
akuntansi Islami) memiliki rata-rata 4,2111 dengan std Deviation 0,45873 yang berarti bahwa responden akuntan pendidik dan akuntan publik setuju terhadap karakteristik akuntansi Islami, hal tersebut ditunjukkan dalam menjawab kuesioner rata-rata menjawab angka 4 yang berarti setuju.

Tabel 3. Deskriptif statistik deskriptif persepsi akuntan pendidik dan akuntan publik terhadap Akuntansi Islami.

\begin{tabular}{lcrrrr}
\hline & N & Minimum & Maximum & Mean & $\begin{array}{c}\text { Std. } \\
\text { Deviation }\end{array}$ \\
\hline KABI & 90 & 3.00 & 5.00 & 4.0256 & .45581 \\
\hline KAI & 90 & 3.10 & 5.00 & 4.2111 & .45873 \\
\hline UAI & 90 & 2.86 & 5.00 & 4.1441 & .61710 \\
\hline TAKTI & 90 & 2.40 & 5.00 & 3.4867 & .67711 \\
\hline Valid N & 90 & & & & \\
(Listwise) & & & & & \\
\hline
\end{tabular}

Sumber: Dokumen peneliti

Berdasarkan tabel 3 dapat disimpulkan bahwa KABI (karakteristik aktivitas bisnis islami) memiliki rata-rata 4,0256 dengan std Deviation 0,45581 yang berarti bahwa responden akuntan pendidik dan akuntan publik setuju terhadap karakteristik aktivitas bisnis Islami, hal tersebut ditunjukkan dalam menjawab kuesioner rata-rata menjawab angka 4 yang berarti setuju. KAI (Karakteristik akuntansi Islami) memiliki rata-rata 4,2111 dengan std Deviation 0,45873 yang berarti bahwa responden akuntan pendidik dan akuntan publik setuju terhadap karakteristik akuntansi Islami, hal tersebut ditunjukkan dalam menjawab kuesioner rata-rata menjawab angka 4 yang berarti setuju.

UAI (user akuntansi Islami) memiliki rata-rata 4,1441 dengan std Deviation 0,61710 yang berarti bahwa responden akuntan pendidik dan akuntan publik menganggap sangat penting para user akuntansi, hal tersebut ditunjukkan dalam menjawab kuesioner rata-rata menjawab angka 4 yang berarti sangat penting. TAKTI (tujuan akuntansi Islami) memiliki rata-rata 3,4867 dengan std Deviation 0,67711 yang berarti bahwa responden akuntan pendidik dan akuntan publik menyatakan penting mengenai tujuan akuntansi Islami, hal tersebut ditunjukkan dalam menjawab kuesioner rata-rata menjawab angka 3 yang berarti penting.

Tabel 4. Hasil uji Validitas Untuk Karakteristik Akuntansi Bisnis Islami

\begin{tabular}{crccc}
\hline $\begin{array}{c}\text { Item } \\
\text { Pertanyaan }\end{array}$ & r hasil & R tabel & Signifikansi & Keterangan \\
\hline 1 & 0,647 & 0,207 & 0,000 & Valid \\
\hline 2 & 0,597 & 0,207 & 0,000 & Valid \\
\hline 3a & 0,627 & 0,207 & 0,000 & Valid \\
\hline 3b & 0,655 & 0,207 & 0,000 & Valid \\
\hline 3c & 0,617 & 0,207 & 0,000 & Valid \\
\hline $4 \mathrm{a}$ & 0,414 & 0,207 & 0,000 & Valid \\
\hline 4b & 0,578 & 0,207 & 0,000 & Valid \\
\hline $4 \mathrm{c}$ & 0,473 & 0,207 & 0,000 & Valid \\
\hline 5 & 0,658 & 0,207 & 0,000 & Valid \\
\hline 6 & 0,754 & 0,207 & 0,000 & Valid \\
\hline
\end{tabular}

Sumber: Dokumen peneliti

Berdasarkan tabel 4, 5, 6, 7 untuk Karakteristik Akuntansi Bisnis Islami, Karakteristik Akuntansi Islami, User Akuntansi Islami, tujuan Akuntansi Islami, disimpulkan semua instrument dalam penelitian ini adalah valid. 
Tabel 5. Hasil uji Validitas untuk Karakteristik Akuntansi Islami

\begin{tabular}{ccccc}
\hline $\begin{array}{c}\text { Item } \\
\text { Pertanyaan }\end{array}$ & r hasil & r tabel & Signifikansi & Keterangan \\
\hline 1 & 0,736 & 0,207 & 0,000 & Valid \\
\hline 2 & 0,565 & 0,207 & 0,000 & Valid \\
\hline 3 & 0,687 & 0,207 & 0,000 & Valid \\
\hline 4 & 0,558 & 0,207 & 0,000 & Valid \\
\hline 5 & 0,629 & 0,207 & 0,000 & Valid \\
\hline 6 & 0,683 & 0,207 & 0,000 & Valid \\
\hline 7 & 0,615 & 0,207 & 0,000 & Valid \\
\hline 8 & 0,614 & 0,207 & 0,000 & Valid \\
\hline 9 & 0,758 & 0,207 & 0,000 & Valid \\
\hline 10 & 0,701 & 0,207 & 0,000 & Valid \\
\hline
\end{tabular}

Sumber: Dokumen peneliti

Tabel 6. Hasil uji Validitas untuk User Akuntansi Islami

\begin{tabular}{ccccc}
\hline $\begin{array}{c}\text { Item } \\
\text { Pertanyaan }\end{array}$ & r hasil & r tabel & Signifikansi & Keterangan \\
\hline 1 & 0,819 & 0,207 & 0,000 & Valid \\
\hline 2 & 0,857 & 0,207 & 0,000 & Valid \\
\hline 3 & 0,796 & 0,207 & 0,000 & Valid \\
\hline 4 & 0,83 & 0,207 & 0,000 & Valid \\
\hline 5 & 0,787 & 0,207 & 0,000 & Valid \\
\hline 6 & 0,831 & 0,207 & 0,000 & Valid \\
\hline 7 & 0,767 & 0,207 & 0,000 & Valid \\
\hline
\end{tabular}

Sumber: Lampiran 6

Tabel 7. Hasil uji Validitas untuk Tujuan Akuntansi Islami

\begin{tabular}{ccccc}
\hline $\begin{array}{c}\text { Item } \\
\text { Pertanyaan }\end{array}$ & r hasil & r tabel & Signifikansi & Keterangan \\
\hline 1 & 0,712 & 0,207 & 0,000 & Valid \\
\hline 2 & 0,777 & 0,207 & 0,000 & Valid \\
\hline 3 & 0,707 & 0,207 & 0,000 & Valid \\
\hline 4 & 0,681 & 0,207 & 0,000 & Valid \\
\hline 5 & 0,722 & 0,207 & 0,000 & Valid \\
\hline
\end{tabular}

Sumber: Lampiran 6

Ukuran untuk menentukan reliabilitas adalah jika suatu kontsruk atau variabel memberikan nilai Cronbach Alpha > 0,6. (Ghozali, 45;2005). Dari tabel 8, semua variabel pada penelitian ini memiliki nilai koefisien alpha jauh lebih besar dari 0,6 sehingga dapat disimpulkan bahwa alat-alat ukur tersebut bisa dikatakan layak untuk mengumpulkan data.

Tabe1 8. Uji Reliabilitas

\begin{tabular}{clcc}
\hline No & \multicolumn{1}{c}{ Variabel } & $\begin{array}{c}\text { Koefisien } \\
\text { Alpha } \\
\text { Cronbach }\end{array}$ & Keterangan \\
\hline 1 & Karakteristik Aktivitas Bisnis Islami & 0,7845 & Reliabel \\
\hline 2 & Karakteristik Akuntansi Islami & 0,8496 & Reliabel \\
\hline 3 & User Akuntansi Islami & 0,9116 & Reliabel \\
\hline 4 & Tujuan Akuntansi Islami & 0,6575 & Reliabel \\
\hline Sumber: Dokumen peneliti & &
\end{tabular}


Pengujian. Berdasarkan pengujian tabel 9, signifikansi sebesar 0,006 lebih besar dari nilai signifikansi pada level 0,05. Maka dari hasil tersebut dapat disimpulkan bahwa terdapat perbedaan persepsi antara akuntan pendidik dan akuntan publik terhadap Akuntansi Islami.

Dari hasil penelitian ini dapat dilihat bahwa persepsi akuntan pendidik dan akuntan publik terdapat perbedaan yang signifikan terhadap Akuntansi Islami, hasil penelitian ini mendukung penelitian serupa yang dilakukan Asnita dan Bandi (2007), yang menyatakan bahwa terdapat perbedaan persepsi antara akuntan pendidik dan mahasiswa akuntansi terhadap Akuntansi Islam.

Perbedaan tersebut kemungkinan muncul karena disebabkan oleh beberapa faktor external yaitu: rata-rata pendidikan terakhir yang ditempuh oleh akuntan pendidik adalah S2 sedangkan rata-rata pendidikan terakhir yang ditempuh oleh akuntan publik adalah S1. Sehingga mempengaruhi mereka dalam menyimpulkan Akuntansi Islam berdasarkan pengalaman dan ilmu, yang telah mereka dapat dari pendidikan terakhir.

Selain itu pengalaman kerja para akuntan juga mempengaruhi dalam menyimpulkan akuntansi Islami, kebanyakan para akuntan pendidik memiliki pengalaman kerja lebih dari 10 tahun, sehingga pemahaman mereka mengenai karakteristik dan tujuan akuntansi Islami lebih luas dibandingkan dengan akuntan publik yang rata-rata memiliki pengalaman kerja kurang dari 5 tahun.

Tabel 9. Independet Sampel T Test

Levene's
Tes for
quality of
Variance

\begin{tabular}{|c|c|c|c|c|c|c|c|c|c|c|}
\hline & & \multicolumn{9}{|c|}{ Variance } \\
\hline & & \multirow[b]{2}{*}{$\mathrm{F}$} & \multirow[b]{2}{*}{ Sig } & \multirow[b]{2}{*}{$\mathrm{t}$} & \multirow[b]{2}{*}{$\mathrm{df}$} & \multirow{2}{*}{$\begin{array}{l}\text { Sig } \\
(2- \\
\text { tiled })\end{array}$} & \multirow{2}{*}{$\begin{array}{l}\text { Mean } \\
\text { Difference }\end{array}$} & \multirow{2}{*}{$\begin{array}{l}\text { Std. Error } \\
\text { Difference }\end{array}$} & \multicolumn{2}{|c|}{$\begin{array}{l}\text { 95\%Confidence } \\
\text { Interval of the } \\
\text { Diffefence }\end{array}$} \\
\hline & & & & & & & & & Lower & Upper \\
\hline $\begin{array}{l}\text { AK. } \\
\text { ISKAM }\end{array}$ & $\begin{array}{l}\text { Equal } \\
\text { variancwe } \\
\text { Assumed } \\
\text { Equal } \\
\text { variance } \\
\text { not } \\
\text { Assumed }\end{array}$ & .809 & .371 & 2.817 & 82.865 & .006 & .2673 & .09488 & .07877 & .45590 \\
\hline
\end{tabular}

Sumber: Dokumen peneliti

\section{SIMPULAN}

Penelitian ini dimaksudkan untuk mengetahui ada tidaknya perbedaan persepsi diantara kedua kelompok yaitu akuntan pendidik dan akuntan publik mengenai Akuntansi Islami. Variabel Akuntansi Islami terdiri dari 4 konstruk yaitu, karakteristik aktivitas bisnis Islami, karakteristik akuntansi Islami, user Akuntansi Islami dan tujuan Akuntansi Islami. Hasil pengujian disimpulkan bahwa secara keseluruhan terdapat perbedaan persepsi yang signifikan antara akuntan pendidik dan akuntan publik terhadap Akuntansi Islam. Banyak faktor-faktor yang menyebabkan terjadinya perbedaan persepsi antara akuntan pendidik dan akuntan publik, misalnya adalah: tingkat pendidikan akhir para akuntan dan pengalaman kerja para akuntan. Hasil penelitian ini mendukung penelitian yang dilakukan oleh Asnita dan Bandi (2007), yang menyatakan bahwa terdapat perbedaan persepsi antara akuntan pendidik dan mahasiswa akuntansi terhadap Akuntansi Islami.

Penelitian ini dirasakan oleh peneliti telah dilakukan secara optimal namun demikian peneliti merasa dalam hasil penelitian ini masih adanya beberapa keterbatasan dalam penggunaan metode survei melalui kuisioner sehingga 
kesimpulan yang diambil hanya berdasarkan pada data yang dikumpulkan melalui penggunaan instrumen secara tertulis dan kendala yang bersifat situasional, yaitu berupa situasi yang dirasakan responden pada saat pengisian kuisioner tersebut akan dapat mempengaruhi cara menjawab. Berdasarkan hasil penelitian dan pembahasan serta kesimpulan, maka beberapa saran yang dapat disampaikan penelitian yaitu degan memperluas lingkup sampel untuk akuntan pendidik, dengan membandingkan antara dosen yang mengajar pada perguruan tinggi yang bernafaskan Islam dengan perguruan tinggi tidak bernafaskan Islam, sedangkan untuk sample akuntan publik dapat memperluas di wilayah Surabaya, agar hasilnya dapat lebih baik.

\section{DAFTAR PUSTAKA}

Adnan, Muhammad Akhyar, 2000, Akuntansi Syariah: Dulu, Kini dan Esok, Makalah pada Seminar Nasional Akuntansi Syari ah, Unbraw, Malang

Adnan, M.A. and Gaffikin, 1997, The Shariah, Islamic banks and accounting concepts and practices. Proceedings of the International Conference 1: Accounting Commerce and Finance: The Islamic Perspective, Sydney, Australia.

Asnita, dan Bandi, 2007, Akuntansi Islam: Persepsi Akuntan dan Calon Akuntan, Makalah Simposium Akuntansi X Makassar.

Ghozali, Imam, 2005, Aplikasi Analisis Multivariate Dengan Program SPSS, Penerbit Universitas Diponegoro, Semarang.

Hameed, Shahul, 2002, "Different Accounting for Different Worldviews The Need for An Islamic Accounting". Artikel disampaikan pada Regional Panel Forum on Islamic Accounting, UMY, Yogyakarta.

Harahap, Sofyan Syafri, 2004, Akuntansi Islam, PT Bumi Aksara, Jakarta.

Haniffa, R. and Hudaib, M. 2001, A conceptual framework for Islamic accounting: The Shari'a paradigm. Paper of the International Conference on Accounting, Commerce \& Finance: The Islamic Perspectiv, New Zealand

Muhamad, 2002, Pengantar Akuntansi Syari ah, Salemba Empat, Jakarta

Nasution, ahmad Sanusi, 2006, Akuntansi Syariah dalam sebuah Tinjauan, http: \\sanoesoi.wordpress.com

Prayudi, 2007, Akuntansi Dalam Kacamata Islam,

http:/ / www.akuntansisyariah.multiply.com

Scott, Dr, 1976, Theory of Accounts, Arno Press, New York.

Susanto, Akhmad, 2002, Zakat Sebagai Pengurang Penghasilan Kena Pajak: Sebuah Tinjauan Makroekonomi, Artikel disampaikan pada Simposium Nasional I Sistem Ekonomi Islam, UII, Yogyakarta.

Triyuwono, I, 2000, Akuntansi Syariah: Implementasi nilai keadilan dalam format metafora amanah (Shariah Accounting: Implementation of justice in a form of trust metaphor), Jurnal Akuntansi \& Auditing Indonesia, 4(1): 1-34.

Yaya, Rizal dan Shahul Hameed, 2004, Objectives and Characteristics of Islamic Accounting: Perception of Muslim Accounting Academicians in Yogyakarta, kota yogyakarta, http://www.iiu.edu.my

Zaid, O.A, 1997, Accounting books and reports in the Islamic State. Proceedings of theInternational Conference 1: Accounting Commerce and Finance: The Islamic Perspective, Sydney, Australia 


\section{Lampiran 1}

\section{INFORMASI DIRI RESPONDEN}

\section{Silahkan isi titik-titik atau beri tanda $(X)$ atau $(\sqrt{ })$ pada jawaban yang tersedia} untuk menjawab pertanyaan berikut:

Nama (boleh tidak diisi)

Jenis kelamin

Agama

Nama perguruan tinggi tempat bekerja/ nama kantor KAP tempat bekerja

Saya pernah mengikuti (mohon ditandai $(\sqrt{ })$ opsi berikut sesuai dengan pengalaman anda):
Seminar
Lokakarya
Perkuliahan
Konferensi Internasional

\section{Tentang Akuntansi Dalam Perspektif Islam}

\section{Bagi Anda Akuntan Pendidik:}

Jabatan Saat Ini

Pendidikan Terakhir

: S1

$\mathrm{S} 2$

S3

Status (untuk jurusan Akuntansi) Negeri

Swasta Disamakan

Diakui

Terdaftar

Lama bekerja sebagai akademis

\section{Bagi Anda Akuntan Publik:}

Jabatan Saat Ini

Pendidikan Terakhir

: S1

S2

S3

Pendidikan/ pelatihan yang pernah diikuti: Auditing

Pendidikan Profesi Lanjutan

Perpajakan

Lainnya

Lama bekerja sebagai auditor 


\section{Petunjuk:}

Berilah tanda silang $(\mathrm{X})$ atau tanda centang $(\sqrt{ })$ pada alternatif jawaban yang Anda anggap paling sesuai dengan pernyataan-pernyataan berikut. Tidak ada jawaban yang dianggap salah, oleh sebab itu semua pertanyaan harus dijawab. Terdapat 5 alternatif jawaban yang tersedia dengan pengertian sebagai berikut:

$$
\begin{aligned}
& 1 \text { = Sangat Tidak Setuju } \\
& 2 \text { = Tidak Setuju } \\
& 3 \text { = Ragu-ragu } \\
& 4 \text { = Setuju } \\
& 5 \text { = Sangat Setuju }
\end{aligned}
$$

\begin{tabular}{|c|c|c|c|c|c|c|}
\hline No & Pernyataan & (1) & (2) & (3) & (4) & (5) \\
\hline 1 & $\begin{array}{l}\text { Organisasi bisnis Muslim (organisasi yang } \\
\text { dikendalikan oleh orang yang beragama } \\
\text { Islam) seharusnya ikut mendorong mencapai } \\
\text { kesukseskan di akhirat, selain pencapaian } \\
\text { kesuksesan di dunia. }\end{array}$ & & & & & \\
\hline 2 & $\begin{array}{l}\text { Organisasi bisnis Muslim seharusnya ikut } \\
\text { mendorong pencapaian kesejahteraan sosial } \\
\text { masyarakat, selaian pencapaian laba } \\
\text { perusahaan. }\end{array}$ & & & & & \\
\hline $3 a$ & $\begin{array}{l}\text { Tujuan organisasi bisnis Muslim seharusnya, } \\
\text { memastikan semua stakeholder diperlakukan } \\
\text { secara adil, meskipun berakibat laba menjadi } \\
\text { lebih rendah. }\end{array}$ & & & & & \\
\hline $3 b$ & $\begin{array}{l}\text { Tujuan organisasi bisnis Muslim seharusnya, } \\
\text { menghidari kerusakan lingkungan oleh } \\
\text { perusahaan, meskipun tidak ada aturan } \\
\text { hukum yang memadai. }\end{array}$ & & & & & \\
\hline $3 c$ & $\begin{array}{l}\text { Tujuan organisasi bisnis Muslim seharusnya, } \\
\text { membayar upah yang memadai bagi para } \\
\text { pekerja untuk hidup wajar, meskipun hal ini } \\
\text { dapat mengurangi keuntungan pemegang } \\
\text { saham. }\end{array}$ & & & & & \\
\hline $4 a$ & $\begin{array}{l}\text { Laporan keuangan yang dibuat berdasarkan } \\
\text { prinsip-prinsip akuntansi konvensional, } \\
\text { dapat memberikan informasi secara tepat } \\
\text { dan benar untuk menunjukkan pertanggung } \\
\text { jawaban perusahaan atas tuntutan Islam } \\
\text { (seperti kepatuhan pada syariah Islam). }\end{array}$ & & & & & \\
\hline $4 b$ & $\begin{array}{l}\text { Laporan keuangan yang dibuat berdasarkan } \\
\text { prinsip-prinsip akuntansi konvensional, }\end{array}$ & & & & & \\
\hline
\end{tabular}

\section{A1.1. Karakteristik aktivitas bisnis Islami}




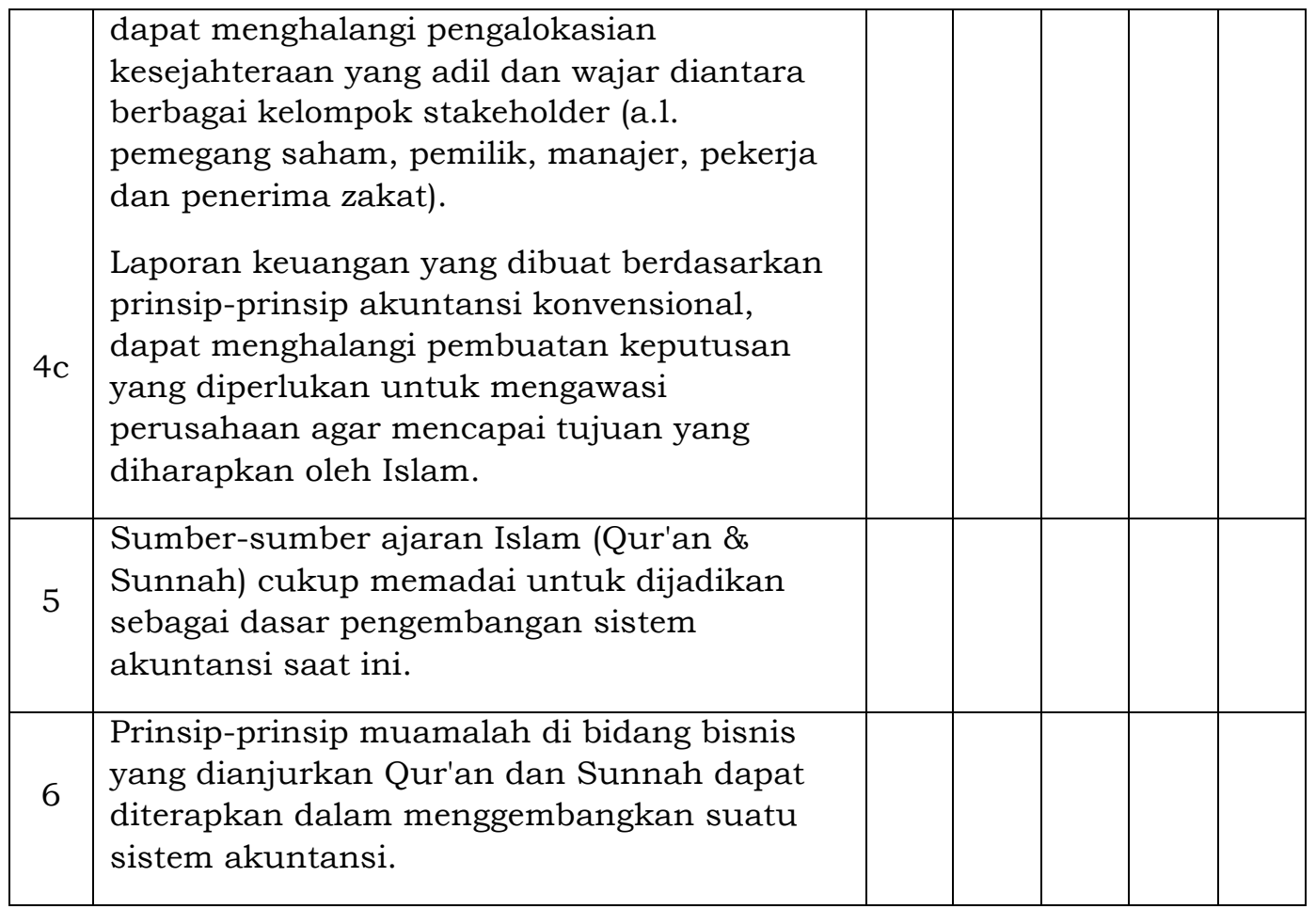

\section{A1.2. Karakteristik Akuntansi Islami}

Pentingnya menyediakan informasi berikut dalam laporan keuangan tahunan organisasi Muslim (dibandingkan dengan informasi tentang laba)

\begin{tabular}{|c|c|c|c|c|c|c|}
\hline No & Pernyataan & (1) & (2) & (3) & (4) & (5) \\
\hline 1 & $\begin{array}{l}\text { Akuntansi dalam perspektif Islam } \\
\text { seharusnya tidak dibatasi pada aspek } \\
\text { keuangan semata. }\end{array}$ & & & & & \\
\hline 2 & $\begin{array}{l}\text { Laporan keuangan akuntansi Islami } \\
\text { seharusnya tidak hanya mencatat kejadian/ } \\
\text { transaksi ekonomi tetapi juga meliputi } \\
\text { kejadian/ transaksi sosial-ekonomi. }\end{array}$ & & & & & \\
\hline 3 & $\begin{array}{l}\text { Laporan keuangan Akuntansi Islami } \\
\text { seharusnya juga mengakui dan mengukur } \\
\text { eksternalitas (seperti dampak lingkungan, } \\
\text { dan sosial sebagai akibat dari kegiatan } \\
\text { organisasi). }\end{array}$ & & & & & \\
\hline 4 & $\begin{array}{l}\text { Laporan keuangan Akuntansi Islami } \\
\text { seharusnya menggunakan nilai sekarang } \\
\text { (current value) dalam neraca untuk } \\
\text { menghitung zakat secara wajar. }\end{array}$ & & & & & \\
\hline 5 & $\begin{array}{l}\text { Rekening (account) dalam laporan tahunan } \\
\text { organisasi bisnis Muslim seharusnya diaudit } \\
\text { untuk memastikan bahwa organisasi } \\
\text { tersebut telah menjalankan kegiatannya } \\
\text { sesuai dengan Syari'ah Islam (audit syari'ah). }\end{array}$ & & & & & \\
\hline
\end{tabular}




\section{Petunjuk:}

Berilah tanda silang $(\mathrm{X})$ atau tanda centang $(\sqrt{ })$ pada alternatif jawaban yang Anda anggap paling sesuai dengan pernyataan-pernyataan berikut. Tidak ada jawaban yang dianggap salah, oleh sebab itu semua pertanyaan harus dijawab. Terdapat 5 alternatif jawaban yang tersedia dengan pengertian sebagai berikut:

$$
\begin{aligned}
& 1=\text { Tidak Penting Sama Sekali } \\
& 2=\text { Kurang Penting } \\
& 3=\text { Penting } \\
& 4=\text { Sangat Penting } \\
& 5=\text { Penting Sekali }
\end{aligned}
$$

\begin{tabular}{|c|c|c|c|c|c|c|}
\hline No & Pernyataan & (1) & (2) & (3) & (4) & (5) \\
\hline 6 & $\begin{array}{l}\text { Dampak aktivitas perusahaan pada } \\
\text { lingkungan sekitar. }\end{array}$ & & & & & \\
\hline 7 & $\begin{array}{l}\text { Hubungan internal antara pemilik- pegawai } \\
\text { dan kondisi kerja. }\end{array}$ & & & & & \\
\hline 8 & $\begin{array}{l}\text { Distribusi gaji, bonus, dan upah di antara } \\
\text { berbagai tingkat manajer dan karyawan. }\end{array}$ & & & & & \\
\hline 9 & $\begin{array}{l}\text { Aktivitas dalam Kegiatan pendanaan yang } \\
\text { dilarang/ diharamkan oleh Syari'ah Islam } \\
\text { yang dilakukan oleh organisasi. }\end{array}$ & & & & & \\
\hline 10 & $\begin{array}{l}\text { Tanggung jawab sosial organisasi terhadap } \\
\text { masyarakat. }\end{array}$ & & & & & \\
\hline
\end{tabular}

\section{A1.2. Karakteristik Akuntansi Islami}

Pentingnya menyediakan informasi berikut dalam laporan keuangan tahunan organisasi Muslim (dibandingkan dengan informasi tentang laba)

\section{A2. User akuntansi Islami}

Harap menunjukkan pentingnya hal-hal berikut sebagai pihak-pihak yang berkepentingan terhadap pengguna informasi akuntansi dalam perspektif Islam (dibandingkan dengan pemegang saham)

\begin{tabular}{|c|l|c|c|c|c|c|}
\hline No & Pernyataan & (1) & (2) & (3) & (4) & (5) \\
\hline 1 & Manajer & & & & & \\
\hline 2 & Pekerja / serikat Perdagangan & & & & & \\
\hline 3 & Pemerintah & & & & & \\
\hline 4 & Masyarakat & & & & & \\
\hline 5 & Kreditor & & & & &
\end{tabular}




\begin{tabular}{|c|l|l|l|l|l|l|}
\hline 6 & Pelanggan / organisasi konsumen & & & & & \\
\hline 7 & Penerima zakat/ amil zakat & & & & & \\
\hline
\end{tabular}

\section{A3. Tujuan akuntansi Islami}

Dari pernyataan dibawah ini mana yang merupakan tujuan utama akuntansi islami?

\begin{tabular}{|c|c|c|c|c|c|c|}
\hline No. & Pernyataan & (1) & (2) & (3) & (4) & (5) \\
\hline 1. & $\begin{array}{l}\text { Untuk menyajikan informasi tentang } \\
\text { jumlah, kepastian dan saat aliran arus kas } \\
\text { pemegang saham guna membuat keputusan } \\
\text { untuk membeli, menahan atau menjual } \\
\text { saham-saham (decision uselfulnes). }\end{array}$ & & & & & \\
\hline 2. & $\begin{array}{l}\text { Untuk menyajikan informasi yang dapat } \\
\text { membantu para pemegang saham } \\
\text { mengevaluasi seberapa evisien manajemen } \\
\text { telah menjaga dan meningkatkan aset } \\
\text { mereka (stewardship). }\end{array}$ & & & & & \\
\hline 3. & $\begin{array}{l}\text { Untuk menyajikan informasi yang dapat } \\
\text { membantu para pemegang saham } \\
\text { memastikan bahwa organisasi telah } \\
\text { melaksanakan tanggung jawabnya sesuai } \\
\text { dengan Syari'ah Islam dan mendorong } \\
\text { perilaku ekonomi agar sesuai dengan tujuan } \\
\text { dan nilai-nilai Islam (Islamic Accountability). }\end{array}$ & & & & & \\
\hline 4. & $\begin{array}{l}\text { Untuk menyajikan informasi guna } \\
\text { membantu perhitungan dan penyaluran } \\
\text { zakat yang secara otomatis memenuhi } \\
\text { kebutuhan pemakai informasi akuntansi } \\
\text { lainnya (Accountability trought zakat). }\end{array}$ & & & & & \\
\hline 5. & Selain di atas, silahkan sebutkan: & & & & & \\
\hline
\end{tabular}

(Sumber: Asnita dan Bandi, 2007) 